\title{
Latent HIV-1 Infection in Enriched Populations of Blood Monocytes and T Cells from Seropositive Patients
}

\author{
M. Juliana McElrath, Ralph M. Steinman, and Zanvil A. Cohn \\ The Laboratory of Cellular Physiology and Immunology, The Rockefeller University, New York 10021
}

\begin{abstract}
The extent of latent HIV-1 infection in blood T cells and monocytes of 23 seropositive individuals was examined using DNA amplification (PCR) of HIV-1 sequences. Amplified DNA was found in at least one cell type in all seropositives tested, including 13 asymptomatic, 5 ARC, and 5 AIDS patients. Amplification with two or more primer sets from the gag, env, LTR occurred in 21 (91\%) patients' T cells and 17 (74\%) patients' monocytes. However, amplification with the LTR primers in monocytes was uncommon.

Among four patients tested, amplified DNA continued to be detected after a greater than one thousand-fold dilution ( $<500$ cells) of both $\mathrm{T}$ cell and monocyte lysates. Repeat analysis after 7-9 mo in five seropositives yielded similar findings in $T$ cells and monocytes, but some variation in the efficacy of amplification with individual primers occurred. There was no difference in those 10 patients who were taking AZT, compared to those who were untreated.

Our results indicate that a fraction $(<1 \%)$ of both $T$ cells and monocytes in blood carry a latent infection in all stages of HIV-1 disease and can serve as reservoirs throughout AZT therapy. (J. Clin. Invest. 1991. 87:27-30.) Key words: HIV-1 • monocyte $\cdot T$ cell
\end{abstract}

\section{Introduction}

The ability of human immunodeficiency virus type-1 (HIV-1) to establish a latent infection in blood cells contributes to the spread of virus to multiple tissues and between individuals. Recent reports indicate that a greater burden of both cell-associated and cell-free HIV-1 can be detected in the blood of seropositive individuals than previously recognized $(1,2)$. The evidence from these studies is based upon measurement of HIV-1 production in a tissue culture system. Application of the polymerase chain reaction (PCR) ${ }^{1}$, which can amplify one to a few copies of the HIV-1 genome within host cell DNA $(3,4)$, permits a more direct and sensitive examination of the extent of latent infection, and in different cell types.

Using PCR, a recent study of AIDS patients reported that CD4+ T cells, but not monocytes, were the major reservoir for

Address reprint requests to Dr. M. Juliana McElrath, Box 280, The Rockefeller University, 1230 York Ave., New York, NY 10021. 1990.

Received for publication 13 March 1990 and in revised form 17 May

1. Abbreviations used in this paper: ARC, AIDS-related complex; ASX, no symptoms; PCR, polymerase chain reaction.

J. Clin. Invest.

(c) The American Society for Clinical Investigation, Inc. $0021-9738 / 91 / 01 / 0027 / 04 \$ 2.00$

Volume 87, January 1991, 27-30 latent HIV-1 infection (5). We independently have surveyed monocytes and $T$ cells from seropositive individuals who have AIDS, AIDS-related complex (ARC), or no symptoms (ASX) using the PCR method. Our results confirm that some T cells carry a latent infection in all stages of disease. However, we also detect HIV-1 DNA in enriched populations of monocytes, even though productive infection may be difficult to elicit from this cell population (6).

\section{Methods}

Venipuncture was performed on 23 HIV-1 seropositive participants in a longitudinal HIV study at the Rockefeller University Hospital. The $70-100 \mathrm{ml}$ of heparinized blood was distributed for complete blood cell counts, CD4/CD8 $T$ cell analysis, and cell separation. Blood from known low risk seronegatives was obtained concomitantly to serve as controls.

Cell separation. As previously described (7), blood mononuclear cells were obtained from the interface of Ficoll-Paque gradients and incubated with neuraminidase-treated sheep red blood cells at $4^{\circ} \mathrm{C}$ for $1 \mathrm{~h}$. T cells, which form rosettes with the red cells, were separated from other mononuclear cells by a second Ficoll-Paque gradient. Contaminating $\mathrm{Fc}$ receptor-bearing monocytes were removed from the $\mathrm{T}$ cell population by panning on bacteriologic petri dishes coated with purified human gamma-globulin (CooperBiomedical, Inc., West Chester, PA) (7) or by adherence onto plastic dishes for $1 \mathrm{~h}$ at $37^{\circ} \mathrm{C}$.

To obtain monocytes, the T cell-depleted (nonrosetting) cells were cultured in Teflon beakers for $<36 \mathrm{~h}$ and then adhered $1 \mathrm{~h}$ onto plastic dishes. By culturing the cells before the adherence step we avoided contaminating dendritic cells and B cells which are loosely adherent immediately upon isolation but much less so after culture. The adherent cells were washed, incubated $15 \mathrm{~min}$ in $3 \mathrm{mM}$ EDTA at $37^{\circ} \mathrm{C}$, and gently pipetted or scraped from the plastic. $\mathrm{CD4}^{+}$or $\mathrm{CD} 8+\mathrm{T}$ cells were not detectable by FACScan flow cytometry (6).

Preparation of DNA lysates. Purified monocytes or $\mathrm{T}$ cells were washed twice with PBS, resuspended at $10^{7}$ cells per $\mathrm{ml}$ of lysis buffer (10 mM Tris- $\mathrm{HCl}, \mathrm{pH} 8.0,1 \mathrm{mM}$ EDTA, $0.001 \%$ Triton X-100, $0.0001 \%$ SDS, and $600 \mu \mathrm{g} / \mathrm{ml}$ proteinase $\mathrm{K}$ ) (Boehringer Mannheim Biochemicals, Indianapolis, IN), and digested $1 \mathrm{~h}$ in a $60^{\circ} \mathrm{C}$ waterbath. The proteinase $\mathrm{K}$ then was inactivated at $95^{\circ} \mathrm{C}$ for $15 \mathrm{~min}$. Lysates were stored at $-20^{\circ} \mathrm{C}$ until use in the PCR reaction.

DNA amplification. We chose three oligonucleotide primer pairs to amplify HIV-1 sequences from conserved regions of the genome: SK38/39, from a 114-bp region of gag (1551-1578 and 1638-1665); SK29/30, from a 104-bp region of LTR (501-518; and SK68/69, from a 141-bp region of env (7801-7829 and 7922-7942) (4). Each tube for PCR contained (delivered in the following order) $50 \mu \mathrm{l}$ mineral oil, 50 $\mu \mathrm{l}$ primer reaction mixture (see below), and $50 \mu \mathrm{l}$ DNA lysate (containing $5 \times 10^{5}$ cells or $\sim 1 \mu \mathrm{g} \mathrm{DNA}$ ). Primer and $\mathrm{MgCl}_{2}$ concentrations were adjusted in the primer reaction mixture to achieve amplification of the highest sensitivity without primer-dimer formation. The reaction mixture contained final amounts (for $100 \mu$ l) of either SK38/39 (20 pmol each), SK29/30 (100 pmol each), or SK68/69 (50 pmol each), in $10 \mathrm{mM}$ Tris- $\mathrm{HCl}(\mathrm{pH} 8.3), 50 \mathrm{mM} \mathrm{KCl}, 1.5 \mathrm{mM} \mathrm{MgCl}_{2}$ (4.0 mM with SK68/69 primers), $0.01 \%$ (wt/vol) gelatin, $0.2 \mathrm{mM}$ of each deoxyribonucleoside triphosphate (dATP, dGTP, dCTP, and dTTP), and 2 units of recombinant Thermus aquaticus (Taq) polymerase (Perkin 
Elmer Corp., Norwalk, CT). All samples were added to the tubes with a positive displacement pipetteman, and care was taken to prevent cross contamination of samples. DNA lysates from seronegatives were used as negative controls in every PCR reaction. The H9 human T cell line infected persistently with HTLV-IIIb (ATCC CRL8543) was diluted with uninfected cells $100-1,000$-fold for use as the positive control in each reaction. DNA amplification was performed in a Perkin-Elmer thermal cycler for 30 cycles, programmed to denature for $1 \mathrm{~min}$ at $95^{\circ} \mathrm{C}$, anneal for $1 \mathrm{~min}$ at $55^{\circ} \mathrm{C}$, and extend for $1.5 \mathrm{~min}$ at $72^{\circ} \mathrm{C}$. To complete polymerization of the amplified products, a 10 -min extension at $72^{\circ} \mathrm{C}$ was added at the end of the 30 cycles. PCR products were stored at $4^{\circ} \mathrm{C}$.

Hybridization of $P C R$ products with HIV-1 probes. Oligonucleotide probes, derived from internally conserved sequences of the amplified region, were used to detect the amplified products. These included SK19 (gag), SK31 (LTR), and SK70 (env) (4). 35 pmol of each probe was $5^{\prime}$ labeled with radioactive $32-\mathrm{ATP}(100 \mu \mathrm{Ci})$ at $37^{\circ} \mathrm{C}$ for $1 \mathrm{~h}$ using T4 polynucleotide kinase (Boehringer Mannheim Biochemicals). Unincorporated label was removed by elution over a Nensorb column (NEN Dupont Products, Boston, MA).

The hybridization reaction contained $10 \mu \mathrm{l}$ PCR product and $5 \mu \mathrm{l}$ probe mixture. The probe mixture consisted of $500,000 \mathrm{cpm}$ of the appropriate probe $(1 \mu \mathrm{l}), 150 \mathrm{mM} \mathrm{NaCl}$ (final concentration), and distilled $\mathrm{H}_{2} \mathrm{O}$. The samples were denatured at $95^{\circ} \mathrm{C}$ for $5 \mathrm{~min}$ and hybridized in solution for $10 \mathrm{~min}$ in a $56^{\circ} \mathrm{C}$ waterbath. The oligonucleotide probe-target DNA heteroduplex was resolved by electrophoresis on a $10 \%$ polyacrylamide gel, operated at $200 \mathrm{~V}$ for $\sim 90 \mathrm{~min}$. The characteristic gel retardation fragment representing the amplified HIV-1 sequences were visualized by autoradiography after exposure to XAR film (Eastman Kodak Co., Rochester, NY) with one intensifying screen for $2-4 \mathrm{~h}$ at $-70^{\circ} \mathrm{C}$
Sensitivity and specificity of the PCR analysis. Reaction conditions of the PCR and hybridization allowed detection of amplified products from HIV-1 infected $\mathrm{H} 9$ cells (diluted with uninfected PBMC) at a level $<5$ cells per reaction. If no characteristic band was visualized, the samples were considered negative. Samples were considered positive if the characteristic gel retardation fragments were detected on the autoradiogram at a moderate to high intensity relative to an undetectable to weak intensity in the negative control.

Samples which failed to amplify with all HIV primer sets were amplified with oligonucleotide primer pairs (GH26 and GH27, 50 pmol each) from a conserved region of the HLA-DQ $\alpha$ locus (8) to determine if the DNA present in the lysate could be amplified. Amplified products were resolved on a composite 3\% NuSieve (FMC Bioproducts, Rockland, ME) and 1\% agarose gel,and visualized by ethidium bromide staining. If PCR products were undetectable by this method, the samples were excluded from the study.

\section{Results}

The clinical parameters of the 23 HIV-1 seropositive patients are shown in Table $\mathrm{I}$. The complete disease spectrum was represented among the group studied: 13 had no symptoms, 5 had ARC, and 5 had AIDS. 10 patients had received AZT antiviral therapy for at least 3 mo before venipuncture. Peripheral blood $\mathrm{CD} 4 / \mathrm{CD} 8 \mathrm{~T}$ cell ratios were typically decreased $(<1.0)$.

Efforts to prevent sample contamination were important for distinguishing true positives with the PCR technique. The gag and more particularly the env primers were more likely to generate false positive PCR products, which emphasizes the

Table I. Clinical Parameters and PCR Analysis of HIV-1 Infection from 23 Seropositive Patients

\begin{tabular}{|c|c|c|c|c|c|}
\hline Patient No. & $\begin{array}{l}\text { Clinical } \\
\text { diagnosis }\end{array}$ & $\begin{array}{l}\text { Antiviral } \\
\text { treatment }\end{array}$ & $\begin{array}{c}\text { CD4/CD8 } \\
\text { cells/ } / \mu \mathrm{l}\end{array}$ & $\begin{array}{c}\mathrm{T} \text { cells } \\
\text { gag/env/LTR* }\end{array}$ & $\begin{array}{c}\text { Monocytes } \\
\text { gag/env/LTR* }\end{array}$ \\
\hline 1 & ARC & AZT & $207 / 1960$ & $+1+1-$ & $-1+1-$ \\
\hline 2 & ASX & $\mathrm{AZT}$ & $1109 / 1357$ & $+1+1-$ & $+1+1-$ \\
\hline 3 & ASX & - & $469 / 765$ & $+1+1+$ & $+1+1-$ \\
\hline 4 & ARC & - & $338 / 857$ & $+/+1+$ & $-1+1-$ \\
\hline 5 & ASX & - & $586 / 987$ & $+/+1+$ & $+1+1-$ \\
\hline 6 & ASX & - & $565 / 849$ & $+1+1+$ & $-1+1-$ \\
\hline 7 & AIDS & - & $172 / 560$ & $+1+1-$ & $+1+1-$ \\
\hline 8 & AIDS & $\mathrm{AZT} / \mathrm{ZOV}$ & $643 / 580$ & $+1+1-$ & $+1+1-$ \\
\hline 9 & ASX & - & $748 / 1016$ & $+/+1+$ & $+1+1-$ \\
\hline 10 & AIDS & - & $252 / 1189$ & $+1-1+$ & $+1+1-$ \\
\hline 11 & ASX & - & $675 / 1073$ & $+/+1+$ & $+/+1-$ \\
\hline 12 & ARC & AZT/ZOV & $368 / 1233$ & $+1+1-$ & $-1-1-$ \\
\hline 13 & ASX & AZT/ZOV & $639 / 826$ & $+1-1-$ & $-1+1-$ \\
\hline 14 & AIDS & AZT/ZOV & $79 / 1215$ & $+1-1-$ & $+1+1-$ \\
\hline 15 & ARC & AZT & $282 / 2270$ & $+1+1-$ & $+1+1-$ \\
\hline 16 & ASX & AL721 & $419 / 1100$ & $+/+1+$ & $-1-1-$ \\
\hline 17 & ASX & - & $397 / 761$ & $+/+1+$ & $+1+1-$ \\
\hline 18 & ASX & AZT/ZOV & $283 / 742$ & $+1+1+$ & $+1+1-$ \\
\hline 19 & ASX & - & $741 / 1123$ & $+1+1-$ & $+1+1-$ \\
\hline 20 & ASX & - & $453 / 1424$ & $+/+1+$ & $+1+1+^{*}$ \\
\hline 21 & AIDS & AZT/ZOV & $204 / 974$ & $+1+1+$ & $+1+1-$ \\
\hline 22 & ARC & - & $240 / 525$ & $+1+1+$ & $+/+/+^{*}$ \\
\hline 23 & ASX & - & $768 / 916$ & $+1+1+$ & $+1+1-$ \\
\hline
\end{tabular}

* DNA amplification with SK38/39 (gag), SK68/69 (env), and SK29/30 (LTR) primers and hybridization with SK19 (gag), SK70 (env), and SK31 (LTR) probes, respectively. Signal detected by autoradiography after $2-4 \mathrm{~h}$ exposure. ${ }^{\ddagger}$ Amplification with $L T R$ primers detected by autoradiography after $18 \mathrm{~h}$ only. 


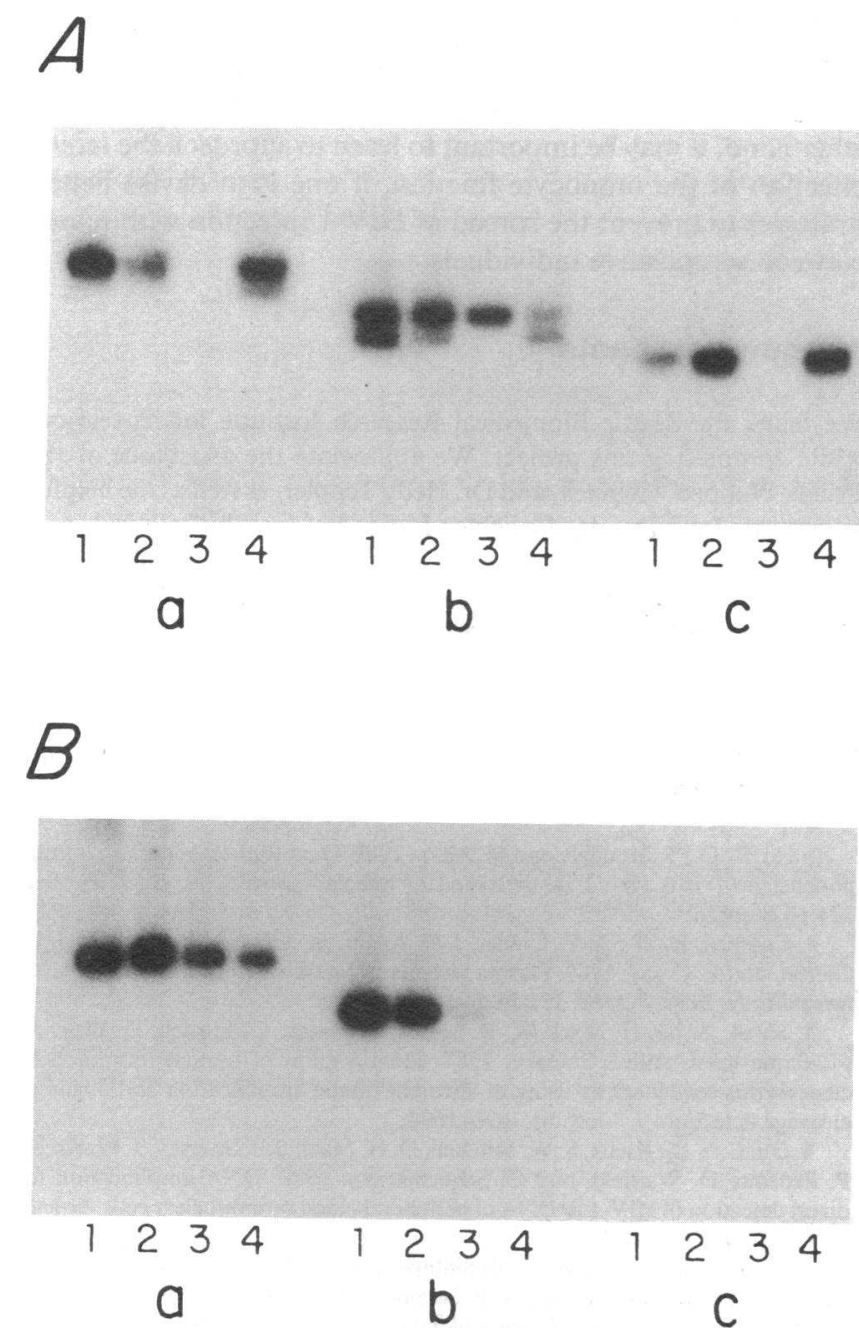

Figure 1. HIV-1 amplified products detected by autoradiography. $(A)$ $\mathrm{T}$ cells and $(B)$ monocytes from patient No. 21 with AIDS (lane 1 ), patient No. 18, ASX (lane 2), patient No. 10 with AIDS (lane 3), and patient No. 4 with ARC (lane 4$)$. Amplification with primers $(a)$ SK68/69 (env), (b) SK38/39 (gag), and (c) SK29/30 (LTR). No fragments were detected by amplification of monocyte DNA with the $L T R$ primers $(c)$.

need to include a negative control with each analysis. The $L T R$ primers were less sensitive but overall more specific in detecting HIV-1 infection, giving no false positives or primer-dimer formation.
Analysis of equal numbers of unstimulated blood $\mathrm{T}$ cells and monocytes from the infected patients by DNA amplification of HIV-specific sequences is shown in Table I. Amplified HIV-1 DNA was detected in at least one primer in all patients' $T$ cells and in $21 / 23$ patients' monocytes. If DNA amplification with two primer sets is considered sufficient to confirm HIV-1 infection, this occurred in 21 out of $23(91 \%)$ patients' T cells and in 17 out of $23(74 \%)$ patients' monocytes. Monocyte lysates but not $\mathrm{T}$ cell lysates from two patients (No. 12 and No. 16), failed to amplify with HIV-1 primers but did amplify with the HLA primers GH26/27 (data not shown), and were therefore considered true negatives.

A typical example of the HIV-1 amplified products with the three primer sets detected by autoradiography is shown in Fig. 1. The signal was apparent in most cases after a $2-\mathrm{h}$ exposure and was confirmed after a 4-h exposure. When present, the signal intensity was generally similar for the two cell types using the gag and $e n v$ primers and corresponding probes. The majority of the $T$ cell samples amplified with $L T R$ primers. Only two monocyte lysates amplified with the $L T R$ primers; reaction products were detected by autoradiography only after an 18-h exposure, which suggests that the amplification may have occurred in a few contaminating $T$ cells.

To assess the relative number of infected cells per sample, serial 10-fold dilutions of the DNA lysates from four patients (Nos. 4, 18, 21, 22) with seronegative PBMC lysates were prepared for PCR. Autoradiography of the hybridized products from patients No. 21 and No. 22 is shown in Fig. 2, and the pattern was similar for patients No. 4 and No. 18. PCR products were detectable to at least a 1,000-fold dilution (500 cells out of 500,000 ) in both the $T$ cell and monocyte samples in all four patients.

PCR analysis was repeated 7-9 mo later in five patients whose course of disease, CD4+ T cells, or management had not significantly changed, and the results are shown in Table II. HIV-1 was detected again in all patients' $T$ cells and in four out of the five patients' monocytes, although there was some variation in amplification with individual primers.

\section{Discussion}

DNA amplification with the PCR technique now affords the opportunity to detect fewer than five copies of HIV-1 DNA in mononuclear cells. In our hands, there is some variability in the detection of HIV-1 by gag and $e n v$ primers, which indicates that at least two sets of primers should be used to confirm HIV infection by the PCR method. It is not clear why the monocyte

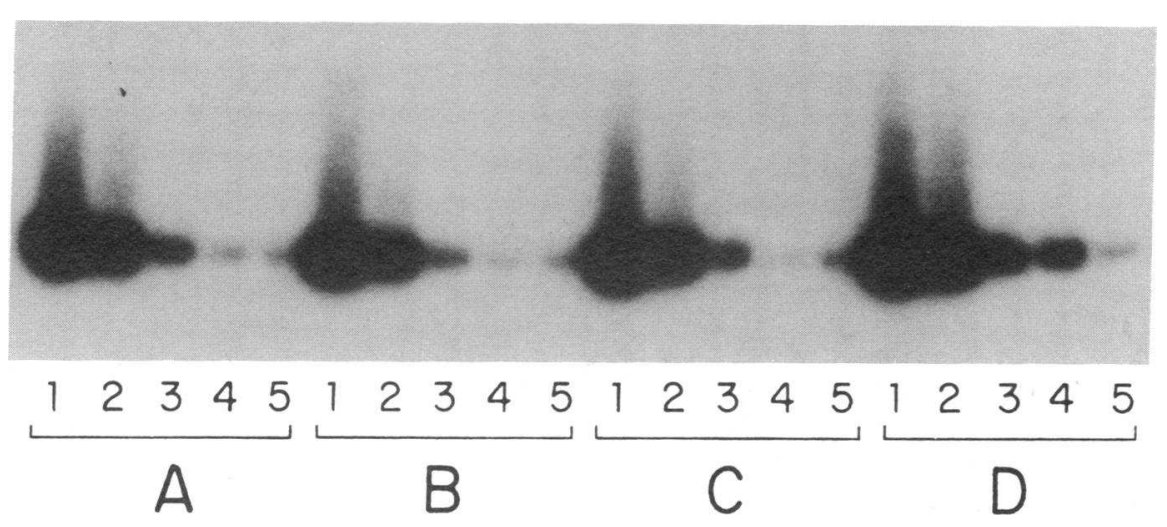

Figure 2. Amplification of 10 -fold serial dilutions of patient No. $21(A, B)$ and patient No. $22(C, D)$ DNA lysates using the SK38/ 39 primers and the SK 19 end-labeled probe. Autoradiography exposure: $3 \mathrm{~h} .(A, C) \mathrm{T}$ cells; $(B, D)$ monocytes. $(1) 5 \times 10^{5}$ cells; $(2)$ $5 \times 10^{4}$ cells; (3) $5 \times 10^{3}$ cells; (4) $5 \times 10^{2}$ cells; (5) $5 \times 10^{1}$ cells. 
Table II. Repeat PCR Analysis of Five Patients for Detection of HIV-I Infection

\begin{tabular}{ccc}
\hline Patient No. & $\begin{array}{c}\text { T cells } \\
\text { gag/env/LTR }\end{array}$ & $\begin{array}{c}\text { Monocytes } \\
\text { gag/env/LTR }\end{array}$ \\
\hline \multirow{2}{*}{1} & $1)+/+/-$ & $1)-/+/-$ \\
& $2)+/+/+$ & $2)-/+/-$ \\
3 & $1)+/+/+$ & $1)+/+/-$ \\
& $2)+/+/+$ & $2)+/+/-$ \\
13 & $1)+/-/-$ & $1)-/+/-$ \\
& $2)+/+/+$ & $2)-/-/-$ \\
& $1)+/+/+$ & $1)+/+/-$ \\
& $2)+/+/+$ & $2)-/+/-$ \\
20 & $1)+/+/+$ & $1)+/+/+$ \\
& $2)+/+/+$ & $2)-/+/-$ \\
\hline
\end{tabular}

Data for the first venipuncture is the same as shown in Table I. The second venipuncture was performed 7-9 mo later.

population failed to amplify with the LTR sequences (Table I, Fig. 1), but we now wonder if these sequences may vary among the various mononuclear cell types.

We found comparable levels of latent HIV-1 infection in the blood cells from 10 patients with early disease $\left(\mathrm{CD}^{+} \mathrm{T}\right.$ cell counts $>500$, Table I) as in those with more progressive disease. Also, AZT-treated individuals, like untreated individuals, were found to have HIV-1 infection in one or both cell types. This finding using PCR analysis is in agreement with other studies measuring viral production $(1,9)$.

Our evidence is that latent infection with HIV-1 occurs in both $\mathrm{T}$ cells and monocytes. This is in contrast to Schnittman et al. (5) who noted that $T$ cells were the principal reservoir. This may reflect differences in the techniques to prepare monocytes. Schnittman et al. sorted with a MAb to the monocyte antigen, CD14. It is possible that latently infected cells were not successfully sorted. Monocytes frequently are lost from the sample because of adherence or clumping during cell sorting procedures, or the latently infected monocyte may have low levels of CD14, an antigen which is subject to downregulation, e.g., by exposure to lipopolysaccharide (Wright, S. W., personal communication). We doubt that our monocytes, which were enriched by plastic adherence after 1-2 d in culture, were significantly contaminated with $\mathrm{T}$ cells, because $\mathrm{CD} 3^{+}$cells were not detectable by FACS analyses (data not shown), and because the level of infection in our $\mathrm{T}$ and monocyte populations seemed similar by dilution analysis (Fig. 2). Our findings regarding the difficulty of eliciting a productive HIV-1 infection from monocytes relative to $T$ cells (6) are similar those of others (5). On the other hand, it may be important to learn to approach the latent infection of the monocyte fraction, if one is to devise better strategies to prevent the spread of HIV-1 infection within and between seropositive individuals.

\section{Acknowledgments}

We thank the Seattle Biomedical Research Institute for its services while completing this project. We appreciate the assistance of Jill Pruett, Philippa Ribbinck, and Dr. Hedy Teppler, as well as the helpful suggestions from Drs. Jan Geliebter, Indira Hewlitt, Shirley Kwok, and Ken Stuart.

This work was supported by the Aaron Diamond Foundation, the National Institutes of Health Grant United States PHS-AI-24775, and in part by the National Institutes of Health General Clinical Research Grant MOI-RR00102.

\section{References}

1. Ho, D. D., T. Moudgil, and M. Alam. 1989. Quantitation of human immunodeficiency virus type 1 in the blood of infected persons. N. Engl. J. Med. 321:1621-1625.

2 Coombs, R. W, A. C. Collier, J.-P. Allain, B. Nikora, M. Leuther, G. F. Gjerset, and L. Corey. 1989. Plasma viremia in human immunodeficiency virus infection. N. Engl. J. Med. 321:1626-1631.

3. Kwok, S., D. H. Mack, K. B. Mullis, B. Poiesz, G. Ehrlich, D. Blair, A. Friedman-Kien, and J. Sninsky. 1987. Identification of human immunodeficiency virus sequences by using in vitro enzymatic amplification and oligomer cleavage detection. J. Virol. 61:1690-1694.

4. Ou, C. Y., S. Kwok, S. W. Mitchell, D. H. Mack, J. J. Sninsky, J. W. Krebs, P. Feorino, D. Warfield, and G. Schochetman. 1988. DNA amplification for direct detection of HIV-1 in DNA of peripheral blood mononuclear cells. Science (Wash. DC). 239:295-297.

5. Schnittman, S. M., M. C. Psallidopoulos, H. C. Lane, L. Thompson, M. Baseler, F. Massari, C. H. Fox, N. P. Salzman, and A. S. Fauci. 1989. The reservoir for HIV-1 in human peripheral blood is a T cell that maintains expression of CD4. Science (Wash. DC). 245:305-308.

6. McElrath, M. J., J. E. Pruett, and Z. A. Cohn. 1989. Mononuclear phagocytes of blood and bone marrow: comparative roles as viral reservoirs in human immunodeficiency virus type-1 infections. Proc. Natl. Acad. Sci. USA. 86:675679.

7. Young, J. W., and R. M. Steinman. 1988. Accessory cell requirements for the mixed leukocyte reaction and polyclonal mitogens, as studied with a new technique for enriching blood dendritic cells. Cell. Immunol. 111:167-182.

8. Sharf, S. J., G. T. Horn, and H. A. Ehrlich. 1986. Direct cloning and sequence analysis of enzymatically amplified genomic sequences. Science (Wash. DC). 233:1076-1078.

9. Burke, D. S., R. R. Redfield, D. S. Bjornson, A. K. Fowler, and C. N. Oster. 1989. Frequent isolation of HIV-1 from the blood of patients receiving zidovudine (AZT) therapy. N. Engl. J. Med. 321:1682. 